\title{
SUPPLY AND PRICING STRATEGIES OF INFORMAL RURAL TRANSPORT PROVIDERS
}

\author{
Christoffel J Venter \\ (corresponding author) \\ Centre of Transport Development and Department of Civil Engineering, \\ University of Pretoria, Pretoria, 0002, South Africa \\ Tel +27-12-420-2184, Fax +27-12-362-5218 \\ (christo.venter@up.ac.za)

\section{Malesela Molomo} \\ Centre of Transport Development and Department of Civil Engineering, \\ University of Pretoria, Pretoria, 0002, South Africa \\ Tel +27-12-420-2184, Fax +27-12-362-5218 \\ (malesela-m@webmail.co.za)
}

\section{Mac Mashiri}

Gwarajena Transport Research and Development, Pretoria, 0043, South Africa

Tel +27-12-348-5008, Fax +27-12-694-2128

(macmashiri@telkomsa.net)

Paper resubmitted to

Journal of Transport Geography

July 2014 
- We examine service patterns and fare levels of informal minibus and pickup truck operators in rural South Africa

- Poisson regression models and qualitative interviews are used

- Empirical evidence shows that poor roads depress public transport frequencies and raise fares

- Rural operators spontaneously develop a service hierarchy in which pickup trucks fill some service gaps left by minibus operators on poor roads 


\title{
SUPPLY AND PRICING STRATEGIES OF INFORMAL RURAL TRANSPORT PROVIDERS
}

\begin{abstract}
Informal paratransit operators using a range of vehicle types (including pickup trucks, small buses, and motorcycles) are a major provider of mobility in rural areas of the developing world. The paper describes a mixed method approach used to examine such operators' decisions around vehicle deployment, route frequency, network organization, and pricing in three rural districts in South Africa. New evidence is presented showing that the condition of rural roads (both paved and unpaved) affects the quantity and quality of public transport services provided, as well as the fares charged to passengers. This strengthens the case for judicious infrastructure investment as a way of improving rural access and livelihoods, and suggests how this might happen by way of leveraging better private sector responses. We also describe the emergence of a differentiated service hierarchy involving a variety of vehicle types suited to different operating conditions, and based on intentional coordination among operators of minibus and pickup truck ('bakkie') services. We argue that governments should promote such coordination and innovation in rural transport markets.
\end{abstract}

Keywords: Rural Transport Services; Poisson Regression Models; Sub-Saharan Africa; Paratransit; Rural Roads.

Word count $=5880$ (excluding abstract, tables and references)

\section{INTRODUCTION: RURAL ROADS, TRANSPORT SERVICES, AND WELFARE}

There is strong international interest in the links between poverty and rural transport. In industrialised countries the question has often been framed in terms of social exclusion, with a growing literature seeking to understand the causes of rural inaccessibility and its effects on the welfare of rural people (e.g. Gray et al., 2006; Smith et al., 2012). Since rural mobility is strongly mediated by access to private transport, there has been a specific focus on potentially non-car owning populations, including elderly and lowincome people and people with disabilities (Kamruzzaman and Hine, 2011; Shergold and Parkhurst, 2012). Potential responses include improved access to public and community transport, reducing car dependence in road design, and greater use of information and communication technologies to enhance connectivity (Gray et al., 2001; Velaga et al., 2012; Parkhurst et al., 2014). 
In developing countries the problems of rural isolation are compounded by two main factors: road infrastructures tend to be significantly less developed, and the incidence of rural poverty is much higher than in industrialised nations. Consequently, the majority of research on rural transport in developing countries has focused on the relationship between rural roads and economic development (Gannon and Liu, 1997; Van de Walle, 2002). The traditional focus of such studies has been on demonstrating and quantifying the effects of rural road investment on production and consumption, either by reducing travel costs or by increasing prices of agricultural produce (e.g. Hettige, 2006; Khandker et al., 2009; Adewunmi \& Francis, 2013). A few studies have gone further to examine the impacts of road investment on market structure and institutions (Mu and Van de Walle, 2011).

It is also widely accepted that rural road investments include significant social benefits, a large part of which cannot be measured in monetary terms. Such benefits include the welfare effects of improved school attendance and access to health care, as well as the risk insurance benefit of improved connectivity to national transport networks (Van de Walle, 2002). Our understanding of these benefits is based, in part, on a rich, largely qualitative literature around the links between rural mobility and livelihoods in developing countries (e.g. Howe, 1981; Barwell, 1996; Porter et al., 2013). This literature has produced an understanding, for instance, of the household and personal costs of excessive walking and porterage (in terms of reduced labour productivity and health), and of the gender dimensions of travel constraints and costs (Porter, 2011; Porter et al., 2012).

Yet while it is generally accepted that investment in rural roads can lead to demonstrable benefits in terms of both conventional monetary indicators and (far less tractable) social indicators, this is not guaranteed. Howe (1981) observed that large investments in road building do not always result in the expected increases in road traffic and economic activity. Hettige (2006) came to a similar conclusion based on case studies of rural road projects in Asia, noting that the traditional assumption that road investment will spontaneously lead to more, better and cheaper transport services does not always apply. "Rural roads are not enough", state Lebo and Schelling (2001), for the same reason. All of these authors argued for a better understanding of the links between infrastructure provision and transport services to allow planners and project implementers to leverage real livelihood benefits more effectively.

This research takes the view that the relationship between infrastructure and services, especially those provided by private sector transport operators, is key to the improvement of rural mobility. A review of the literature shows, however, that motorised rural transport services have received much less research attention than has rural roads. One reason for this is that transport services in much of the developing world have moved from being a public undertaking to being in the private sector domain, where they tend to be largely ignored by transport planners, governments and donor agencies (Ellis and Hine, 1998). The demise of big public intercity bus operators in Africa, Latin America and Asia in the last few decades has left a void that has been filled by informal or paratransit operators, typically using smaller buses, pickup trucks, and 
motorcycles (Barwell, 1996; Gwilliam, 2008). Recent studies show that informal services are now major mobility providers in much of Africa (for instance Uganda's boda-boda and Tanzania's motorcycle taxis (Howe, 2003; Porter et al., 2013)), and Asia (e.g. Cambodia's modified pickups (Ericson, 2011)).

The above studies are part of a growing literature examining the informal public transport sector in developing countries (e.g. Boudreaux, 2006; Gilbert, 2008; Schalekamp \& Behrens, 2010; Venter, 2013). Informal operators tend to have several characteristics in common, including (Gwilliam, 2008):

- Adoption of an informal business model operating largely outside of the ambit of government regulation and control. Unprofessional management practices and poor access to credit tend to lead to the use of old and unreliable vehicles and poor maintenance practices.

- Self-regulation often evolves as a way of allocating economic rights among competing operators. Providers tend to organize into informal associations or unions, which exercise de facto control over fares, route allocation, and the quantity of service.

- This often leads to uncompetitive practices and pricing at higher than competitive market levels (Ellis and Hine, 1998; Hettige, 2006), as well as a user experience that is often one of low service quality, erratic availability, high prices, and poor road safety.

- Vehicle sizes are typically smaller than big buses, due to affordability constraints and sometimes the constraints imposed by adverse operating conditions (e.g. poor roads).

What the handful of studies further highlights is the shortage of knowledge that exists in academic and government circles about exactly how these informal services operate: how decisions are made, for instance about which routes to operate; what drives the entry decision for individual operators, what kind of vehicle to use, and at what level to set fares. Furthermore, most studies have focused on urban conditions. This knowledge gap often reflects in the public transport plans prepared by consultants for rural areas, which tend to be based on urban practices, but ignore rural realities such as the wider range of vehicle types in use, the considerable impact of bad road conditions on transport operating costs, and taxi associations' practice of using old vehicles retired from urban areas for rural services. Clearly, obtaining a deeper understanding of rural transport services in general requires a specific focus on the conditions and constraints of informal operators.

So what is known about the drivers of quality and quantity in rural public transport services? Firstly, there is evidence of a direct link between poor road conditions and high vehicle operating costs: this tends to reduce profitability of passenger services, sometimes to the point where no service can profitably be provided given local affordability limits (Raballand et al., 2011). The low ability of users to pay is a second constraining factor (Ellis and Hine, 1998). Thirdly, road conditions may limit the types 
and sizes of vehicles used, such as the case with boda-boda motorcycle taxis in Uganda where more conventional services are uneconomical or physically impossible (Howe, 2003).

A fourth factor constraining the availability and affordability of rural transport services is low demand densities (Ellis and Hine, 1998). Starkey et al. (2002:19) blame insufficient services on 'the absence of a critical mass of users and operators'. Fifth, information asymmetry between users and operators creates conditions where operators fail to operate effectively, leading to a mismatch between demand and supply. Sixth, low supply coupled with aggressive self-regulatory practices constrains competition: Hettige (2006:12) finds that 'competition is clearly the critical precondition for the development of better transport services.' In this regard Hettige (2006) sees the lack of diversity in vehicle types and sizes as a problem, arguing that a diversity of vehicle types is important to keep transport costs to a minimum and ensure that all transport needs are met.

Overall, then, while the potential for rural road investment under the right conditions to enhance economic and household welfare is not contested, there is as yet a weak understanding of how this actually happens. It is especially the role of rural public transport operators as intermediaries in the rural mobility chain that needs study. How do operators respond to improved infrastructure (if at all), and do these responses translate into improved accessibility for users? Is there empirical evidence to indicate the scale of the supply elasticity to road investment? In this paper we seek to understand operators' business practices and decisions around supply, vehicle deployment, network organization, and pricing.

Accordingly, the objectives of this work are:

- To examine the extent and characteristics of public transport supply in selected rural areas of South Africa;

- To identify the factors determining the service patterns (including routes served, frequencies, fares charged, and vehicle sizes to be used) of informal rural public transport operators, and to quantify the strengths of these relationships; and

- To develop evidence-based recommendations on how rural mobility may be strengthened, with specific reference to informal modes.

We take a case study approach, focusing on three typical rural districts within South Africa. While the focus is primarily on motorized (thus longer-distance) passenger transport, linkages to Intermediate Modes of Transport (IMTs) and freight movement are identified. We do not examine the demand for rural transport or any particular mode in detail, focusing instead on supply and supply-demand interactions.

The paper firstly provides a brief description of the study methodology and data collection. We then discuss findings, including qualitative analyses and statistical modeling of supply and pricing patterns. Lastly, we identify measures that could increase supply, affordability, and use of motorized transport services in rural Africa. 


\section{DATA COLLECTION}

A mixed data collection strategy was used, including both quantitative and qualitative components. Mixed methods have been found useful in rural transport research to overcome issues of data scarcity (Broegaard et al., 2011; Porter et al., 2013). We used quantitative cross-sectional data on the extent and characteristics of a representative sample of rural public transport (including bus, minibus-taxi and pickup truck (so-called 'bakkie') services) to examine supply and pricing patterns under actual operating conditions. This is supplemented with qualitative data, collected via in-depth semistructured interviews with operators, managers and government role players, to investigate perceptions and strategies affecting taxi/bakkie supply.

\section{$2.1 \quad$ Case study areas}

Three rural districts considered representative of the variation of rural transport conditions found across Southern Africa were selected. The areas cover a range of rural conditions, including deep rural/isolated, district centre, commercial agriculture, and mining economy areas. The location of each area relative to major settlements is shown in Figure 1. Located in the Mpumalanga and Limpopo Provinces of South Africa, they include:

- Bushbuckridge Local Authority

- Makhuduthamaga Local Authority

- Greater Tubatse Local Authority

Bushbuckridge Local Authority was declared a presidential nodal point by the president of the republic in 2001 (Bushbuckridge LM, 2010a). The 2007 estimated population was 509,967 and the number of households was 153,839. Only about $9 \%$ of the municipality's population lives in district centres, while small rural villages and sprawling rural smallholdings comprise the remaining $29 \%$ and $61 \%$ of the population respectively (Bushbuckridge LM, 2010b). The local economy of Bushbuckridge depends on agriculture and tourism. However, the fragmented settlement pattern prevents a "critical mass" from being achieved in order to boost and sustain economic growth. Very little commercial farming takes place in Bushbuckridge and several orchards and plantations are currently lying dormant due to limited access to water and numerous land claims on agricultural land (Bushbuckridge LM, 2010b).

Makhuduthamaga Local Authority covers a large area of approximately 2,096 square kilometers, made up of 146 settlements with a population of 300,206 people and 56,642 households (Makhuduthamaga LM, 2010). Yet economic activity is sparse: two minor towns contain most services (namely Jane Furse and Monsterlus, which is located on the edge of the municipal area). There is an unemployment rate of between $60 \%$ and $75 \%$ in the area, and hence high dependency rate on government grants. Government is the largest contributor to employment in the area at $46 \%$, and the sector provides public and social services such as health and education as well as investment in infrastructure development. 
The Greater Tubatse Local Authority is highly mountainous, so development occurs mostly in valleys where settlements are small and scattered. Development potential and spatial patterns are determined by the location of steep ridges (Greater Tubatse LM, 2010). The estimated 2007 population is 343,468 with 66,611 households. Greater Tubatse Municipality has significant mining and manufacturing (ferrochrome smelter) sectors concentrated near district towns; yet unemployment is still significantly above the provincial average.

\section{$2.2 \quad$ Data}

Background data was obtained from government reports and plans such as Integrated Development Plans and Current Public Transport Records. Demographic data such as population and economic activity came from public databases. Consultations with local authority officials helped identify the taxi associations in each district, with whom informal meetings were held to explain the project, to obtain buy-in and access, and to generate an initial understanding of taxi and bakkie operations in each area.

Many taxi services stage at formal and informal ranks in towns and at major transfer points (see Figure 2). Quantitative data collection included rank surveys where data was collected on routes served, vehicle types, departure frequencies, fares, and rank facilities. Cordon surveys at key points along routes provided a 9-hour frequency count (per vehicle type), and all routes were driven by researchers to visually assess road conditions and collect GPS coordinates. Maps of all informal public transport routes were identified with the operators. A total of 76 routes were identified for all three areas. By differentiating between the forward movement in the morning peak (06h00 to 12h00) and the reverse movement in the afternoon peak (15h00 and 18h00), we obtained a total of 152 routes. (The final sample contained 151 routes as one reverse route could not be surveyed due to conflict within one of the associations.)

We recruited and trained 24 local youths -- twelve from the Kgautswane Community Centre and twelve from Bushbuckridge - to act as data collection assistants. A supervisor was also appointed and trained to assist with logistical arrangements and data capturing. Most of the youths from both areas had finished high school but were unemployed.

In-depth interviews were then conducted with managers of three taxi associations in each district, to understand what factors affect the decision of individual associations to operate a service on a particular road in a particular market. The open-ended interview covered broad issues around service quantity (e.g. how do they decide what frequencies to operate at, or which vehicles to use on a particular route?), pricing (how are fare levels determined?), travel demand, cost factors (profit margins and the effect of road conditions), trip distances, and competition from other operators.

The findings of the interviews were presented to the institutional stakeholders in order to strengthen their own understanding of the private sector transport operating 
environment. The qualitative findings also act as a check on the findings of the quantitative cross-sectional analysis.

\section{FINDINGS}

The quantitative and qualitative data covered a wide range of issues relating to the supply of informal transport in the case study areas. We focus here only on analyses of the relationships between informal transport and road quality; vehicle types and their organization into networks; and factors affecting the frequency and pricing of these various informal services.

\subsection{Public transport routes and road infrastructure}

Figure 1 shows the spatial patterns and public transport routes for Bushbuckridge, Makhuduthamaga and Greater Tubatse local authorities. The manner in which local topography affects network patterns is evident when comparing Greater Tubatse - with its long routes along narrow valleys - with the denser coverage of Bushbuckridge and Makhuduthamaga. The many dead-end routes and lack of connectivity in Greater Tubatse can be expected to raise fares or depress frequencies, due to the greater risk operators bear under such conditions (Ellis and Hine, 1998).

Routes are also much longer in Greater Tubatse than in the other two areas. Table 1 shows that the 23 routes surveyed in Greater Tubatse cover 735 route-kilometres, at an average of $31.9 \mathrm{~km}$ - much longer than the averages of $18.6 \mathrm{~km}$ and $15.9 \mathrm{~km}$ in Makhuduthamaga and Bushbuckridge respectively. These longer routes result in more route-kilometers per capita being operated in Greater Tubatse, but at a lower frequency (as will be shown below) and thus lower availability.

Differences in government capacity between the areas are also evident when comparing road conditions. Table 1 summarizes road conditions for all public transport routes in the three case study regions. Road conditions were classified using visual inspection using standard classification procedures while being travelled by $a$ researcher in a probe vehicle.

Approximately $26 \%$ of the surveyed routes in Makhuduthamaga are in poor and very poor condition, 28\% in Greater Tubatse, and only 10\% in Bushbuckridge. Only 10\% and $5 \%$ of the Makhuduthamaga and Greater Tubatse networks, respectively, are in excellent condition, as compared to $27 \%$ in Bushbuckridge. Since the areas are broadly similar in climate and traffic conditions, we could attribute this difference mostly to differing capacities of the three local authorities to manage and maintain their road infrastructure, as well as the extent of historical backlogs. Furthermore both Makhuduthamaga and Greater Tubatse fall within the same district administration, which struggles to manage its district roads. Bushbuckridge, on the other hand, has 
been designated a presidential nodal point, which has given it access to preferential budgets and technical expertise from national government.

The impact of poor road conditions on transport supply and prices is examined later.

\subsection{Vehicle differentiation and network organization}

Four vehicle types operate passenger services in these areas: buses, minibuses, bakkies, and a collection of other small vehicles. Figure 2 shows examples of different modes observed in the study areas. Bus services are the only formal, scheduled services, operated under contract to the provincial authorities and subsidized by government. The typical vehicle is a rugged 65-seater high-floor bus.

Minibus-taxi services are operated with 16 or 18-seat vehicles. A large proportion of minibuses observed here are new vehicles, partially funded in terms of the South African government's Taxi Recapitalisation Programme which provided legal taxi owners with an incentive to scrap and replace old vehicles with newer models with enhanced safety and passenger comfort features. Bakkie services use pickup trucks or light delivery vehicles (LDVs), with or without canopies for passenger protection. A variety of other passenger vehicles, collectively called 'Kartjiebans', include old taxi vehicles or small Venture vans. Both have a typical seating capacity of about 6 to 12 passengers. In Tubatse old sedan vehicles (called "4+1"s) were also observed.

Although minibus-taxi operators are legally required to possess operating licences and thus fall within the ambit of government regulation, we found that many do not operate with licenses, making them de facto informal operators with internal control over all aspects of their service. Bakkies and kartjiebans do not have permits or operating licenses, and are not formally acknowledged as passenger vehicles by law.

Despite their precarious legal status, bakkies contribute a sizable $11 \%, 8 \%$ and $16 \%$ of public transport capacity in Makhuduthamaga, Bushbuckridge, and Greater Tubatse respectively (Table 3). Overall bakkies, minibuses and kartjiebans provide more than $85 \%$ of public transport service, making them by far the most important mobility provider.

All informal operators tend to operate on fixed routes, but with flexible schedules, typically departing only when full. Yet average utilisation is only around $50 \%$ to $60 \%$ of capacity (Table 3), as most passenger movement is heavily directional, leaving drivers very little opportunity for selling the same seat twice on a single trip. Low capacity utilisation contributes to poor financial performance in rural transport markets.

The manner in which the services of minibus-taxis, bakkies and kartjiebans are differentiated becomes obvious when one examines the road types used by each (Figure 3 and Table 2). Minibuses tend to operate predominantly on surfaced roads; the higher the road quality, the higher the taxi frequency. For instance, in Bushbuckridge, $78 \%$ of minibus-taxi supply is on surfaced roads; of this 9 out of 10 taxis ply on roads 
with an excellent or good condition. Average frequencies (in terms of vehicles per hour) are about ten times higher than on roads in fair or poor condition. This was confirmed during the qualitative interviews where the operators indicated that they do not prefer to deploy their vehicles on gravel roads as it reduces the life-span of a vehicle. They indicated that vehicles operating on gravel roads would typically break down within two years of purchase, leaving them with high maintenance and capital repayment costs for the duration of the contract. Eight of the nine associations identified poor roads as one of their main operational challenges.

Operators estimated the average age of minibus taxis at less than 6 years - an indication of the success of government's Taxi Recapitalisation Programme. However an unintended consequence of this success appears to be a gradual withdrawal of minibus services from lower quality rural roads.

The gap is clearly being filled by bakkies and, to a lesser extent, kartjiebans. Overall, $78 \%$ of bakkie supply is on gravel roads (Figure 3 ). About half of this is on gravel roads in poor condition. Kartjiebans and other small vehicles are lowest in the hierarchy, with almost $90 \%$ of their routes restricted to gravel roads.

The allocation of vehicle types to routes is the result of careful and rational decision making on the part of associations. Firstly, associations of minibus operators dominate route allocation; they would normally deploy their vehicles on busier corridors with proper infrastructure. By mutual consent the potential market is divided up between associations into non-overlapping geographical areas. This avoids direct competition on the route. Incursion of these informal "property rights" is often met with violence. Service areas are not, however, determined with user convenience in mind, leading to sometimes fragmented routes, unnecessary transfers, circuitous routings, and even complete withdrawal of service from conflicted areas.

Although bakkie and minibus operators are traditionally in conflict over the right to operate, we found evidence of emerging coordination between them. Most operators of bakkies and kartjiebans are not formal members of taxi associations, but are coopted to provide feeder services along low quality local roads, but only up to the main road network where passengers have to transfer to a minibus for the last leg of the trip to town. This arrangement clearly benefits the minibus operators by consolidating demand. It also benefits bakkie operators, many of whom are aspirant minibus owners, who now have an entry point into the association. It can however be said to disbenefit passengers, who incur sometimes lengthy waits and discomfort at the transfer point. However, associations indicated that, without the lower-quality bakkie and kartjieban vehicles, they would not be willing to penetrate as deeply into rural areas.

\subsection{Factors affecting service frequencies}

In order to further examine the factors affecting the quantity of service by different vehicle types deployed on specific routes, we estimated two advanced cross-sectional 
models on the data. The dependent variables were the peak-period frequencies of (i) all informal public transport, and (ii) only minibus service on each route, expressed as the number of one-way vehicle trips per 3-hour period, during either the 6-9am morning peak or the 3-6pm afternoon peak period.

As these data are not continuous but non-negative integer values, a multiple linear regression model could not be used, and a Poisson regression model was specified instead. The Poisson regression model is a count data model that expresses the probability of a non-negative, integer outcome $y_{i}$ (in this case the number of vehicle trips per route $i$ ), as

$$
P\left(y_{i}\right)=\frac{\exp \left(-\lambda_{i}\right) \cdot\left(\lambda_{i}\right)^{y_{i}}}{y_{i} !}
$$

where $\lambda_{i}$ is the expected value of $y_{i}$. This variable is specified as a function of a set of explanatory variables $X_{i}$ such that $\lambda_{i}=\exp \left(\beta X_{i}\right)$, with the coefficients $\beta$ estimated using maximum likelihood methods. Poisson regression models are frequently used to examine factors contributing to the number of accident occurrences on a given road section (Washington et al., 2003).

By treating trip frequencies during the morning and afternoon periods on the same route as separate observations, we are introducing cross-sectional heterogeneity across observations: forward and return services with overlapping alignments share certain route-specific characteristics such as land use densities. This leads to correlated error components. We allowed for this by specifying a random effects model allowing serial correlation across observations using the same route. Unfortunately no goodness-of-fit statistic can be calculated for the overall model, but the significance of individual variable estimates reflects the strength of individual effects on the dependent variables, which is our main concern (rather than obtaining a predictive model). $P$ values for individual parameter estimates may be interpreted in the standard way: $p$ values below 0.05 indicate statistical significance at a 95\% level of confidence.

Twenty-three potential explanatory variables were tested, including variables describing the quality of road and rank infrastructure, route lengths, population densities within various buffers from the route and the origin and destination, the extent of economic activity within these buffers, competition from other modes, and location effects related to each study area (captured as dummy variables).

Table 4 shows the results of the two best models, containing only significant effects of non-correlated independent variables. The results show significant effects that both confirm previous research and shed further light on supply processes.

The models firstly confirm that service frequencies are related to both the demand density (indicated by the population per hectare resident within $500 \mathrm{~m}$ of the route) and the users' ability to pay (indicated by the Gross Value Added (GVA) per hectare within 2 kilometers of the route). The $500 \mathrm{~m}$ buffer for demand density worked much better than 
larger buffers, suggesting that transport service frequencies respond to the immediate catchment area around a route.

More interesting is the way in which infrastructure, route length, and competition affect supply. As hypothesized, poor quality gravel roads clearly depress minibus frequencies, but not those of other informal modes such as bakkies and kartjiebans (note the insignificance of the \%GRAVPOOR variable in Model 1). Taxis are more likely to increase frequencies where formal taxi ranks are supplied, as these also attract other economic activity such as informal trading and increase potential transport demand. ROUTELENGTH is only marginally significant, indicating that there may be a tendency among informal operators to avoid long routes, especially those longer than $30 \mathrm{~km}$ (oneway), the distance beyond which it becomes impossible to make more than one trip in the peak period.

Lastly, a positive correlation was observed between both all-informal and minibus-taxi frequencies, and the frequency of formal bus trips operating along the same route. This effect could not be incorporated in the multivariate model above as bus trips are also highly correlated with the demand density independent variables. The finding suggests that formal and informal public transport services are complementary rather than substitutes for each other. Previous research has indicated that busses typically serve commuters with repetitive daily travel patterns, whereas informal transport suits passengers in need of flexibility (Venter and Venkatesh, 2009) - thus the markets are not perfectly overlapping. In fact most associations felt their relationship with the bus industry to be generally healthy.

\subsection{Pricing of informal public transport}

Figure 4 shows the average fare per unit distance charged by public transport operators in the case study areas. Bus fares are significantly lower than those of other modes, mainly due to the fact that busses are subsidized. This was reiterated by the informal transport providers, who felt that subsidies were the biggest competitive advantage of the bus mode.

On average, bakkies and kartjiebans charge a slightly higher fare than taxis, but Figure 4 shows that this is mostly due to road conditions as bakkies and kartjiebans operate primarily on gravel roads. There is a strong relationship between road type and condition, and the average fare charged by informal operators. Bakkie fares are on average $65 \%$ higher on gravel than on surfaced roads; for minibuses the figure is $28 \%$. Operators pass the extra operating costs associated with bad road conditions on to users. There might also be an element of monopoly pricing involved, as the bakkies tend to operate in areas with no other services. Surprisingly, though, none of the associations cited infrastructure as a determining factor when setting fare levels.

The general sense of business confidence among rural public transport providers is quite low. During engagements with the operators and management, it was indicated 
that many do not perceive their business as profitable or sustainable, but since economic opportunity is limited they do not leave the industry.

To determine the relative contribution of various factors to the price of informal public transport, we estimated a third regression model taking the average per-kilometer fare as the (continuous) dependent variable. A similar set of explanatory variables was tested as in the frequency models described above, and a similar random-effects specification was used to allow for cross-observation correlation. We also estimated the marginal effects of each significant variable to indicate the effect on the average fare of a unit increase in the independent variable. Results are given in Table 5.

Prices are most strongly influenced by the type of vehicle (\%NONTAXI), location (MUNICIPALITY), and road condition (\%GRAVPOOR). Everything else being equal, bakkie or kartjieban services add $25 \%$ to the price regardless of the road condition, indicating that a measure of monopoly pricing is indeed at play on routes where no minibus competition is present. Across all informal modes, operating only on poor gravel roads adds about $50 \%$ to the price. Informal operators do not charge higher fares on lower demand routes (population density is not significant). The negative sign of the location dummy coefficient captures the fact that routes are much longer in Tubatse, and per-kilometer fares are typically lower on longer distance routes ${ }^{1}$. There is no evidence that the disconnected route structure in Tubatse raises fares, as hypothesised. Lastly, informal modes charge higher fares on routes also plied by formal buses, supporting the earlier suggestion that formal and informal services are complementary rather than competing services.

\section{CONCLUSIONS: IMPLICATIONS FOR RURAL TRANSPORT SERVICES}

The paper describes the characteristics of supply and pricing strategies of informal rural public transport operators in South Africa. The research provides statistical and qualitative confirmation of previous findings around the factors driving transport supply in rural areas of the developing world, but adds significant new insights that can help shape more effective responses to the rural mobility challenge.

We find strong evidence that the condition of roads (both paved and unpaved) is a very important determinant not only of the quantum of service, but also the quality of vehicle used. Minibus vehicles are not likely to be deployed on badly maintained or unpaved roads, even if taxi associations have legal permits/operating licenses for operating along a certain route. Thus minibus-taxi services are predominantly deployed on surfaced roads, and offer higher frequencies on surfaced roads with better conditions. There is anecdotal evidence, for the first time, that the situation is being exacerbated by

\footnotetext{
${ }^{1}$ The effect of distance on unit fare could not be tested directly as route length is used as the denominator of the dependent variable, causing endogeneity problems if route length is also used as an independent variable in the estimation.
} 
government-driven efforts to upgrade and renew the minibus vehicle fleet through the South African Taxi Recapitalisation Programme. While there is an improvement in vehicle and service quality, operators are hesitant to deploy newer (more expensive) vehicles on poor quality roads. This leads to a reduction in supply of quality rural transport services - a clear example of an unintended consequence of well-meaning government intervention in the informal transport sector.

The research also showed that poor quality gravel roads increase average fares by half. Operators pass the extra vehicle operating costs on to passengers. While road condition is not the only factor driving supply and pricing, there remains a strong rationale for using (appropriate) infrastructure improvement strategies as a way to leverage better and more affordable private sector transport services in rural areas.

What are the implications for rural road investment? The suppression of vehicle frequencies was more strongly correlated with the proportion of poor gravel roads than with the extent of paved roads in the dataset. This suggests that upgrading gravel roads from poor to good condition can have a significant incremental impact on service availability and fares, without necessarily upgrading them to a paved road standard. Operators avoid or reduce frequencies on overly long routes - the research suggested a threshold route length of around $30 \mathrm{~km}$ (one-way). Judicious road investments would thus focus on missing links to reduce route lengths, dead-ends, and detours. The research also found that minibus operators are attracted to routes with formalized ranks at their end points - ranks generate other economic activity such as trading, which increases transport demand. This lends support to the provision of rank infrastructure as a way to promote private sector transport supply.

On gravel roads and (to a lesser extent) some surfaced roads in poor condition, the mobility gap is often bridged by 'second tier' operators providing services with pickup trucks ('bakkies'), old low-quality minibus vehicles, or sedan taxis. Although these operators are often ignored by government, they provide a significant amount of transport - almost a third of public transport supply in the case study areas. We also found evidence of intentional coordination between bakkie and minibus operators, leading to a rational organization of routes and vehicle types where bakkies and smaller vehicles provide feeder services along poor quality local roads up to main roads, and minibuses serve major routes to district centres.

Thus a differentiated service hierarchy is emerging involving a greater variety of vehicle types suited to different operating conditions, mirroring recent trends among motorcycle taxi operators in East Africa and Asia (Howe, 2003; Porter et al., 2013). This is encouraging, as it presents evidence of the kind of local innovation that has been seen as a prerequisite for improved rural mobility (e.g. Barwell, 1996; Ellis and Hine, 1998). Perhaps governments' role in this regard should be to find ways of enabling and supporting such innovation and coordination, while treading lightly with regard to regulating competition. While we found some evidence of uncompetitive pricing resulting from such in rural transport markets, it seems equally clear that rural mobility benefits significantly from this differentiated approach, especially the most isolated 
communities who would otherwise have no motorized transport option available. There is a danger in over-emphasizing competition as a means of promoting better rural transport services, as is sometimes done in the literature; cooperative and selforganising approaches (albeit quasi-monopolistic) might be more beneficial to users in marginal markets.

Informal rural transport operators indicate that they are operating at very low profit margins. Many do not perceive their businesses as sustainable. Rural mobility would certainly benefit, in the long run, from active government involvement in the promotion of sustainable business practices through information provision, training, and corporatization of informal transport providers.

Lastly, the work has implications for the theory and practice of project assessment in rural areas. Current economic evaluation methodologies used to assess the benefits of rural infrastructure investments do not generally take the supply response of public transport operators into account, apart from the overall traffic growth considered. Where road investments leverage greater availability and affordability of public transport, significant additional social benefits may be delivered in terms of improved access to opportunities. More research is needed to quantify supply elasticities, and to understand the conditions under which they may be maximized.

\section{ACKNOWLEDGEMENTS}

This work was funded by the UK government's Department for International Development (DFID) under the African Community Access Programme (AFCAP). Their support is gratefully acknowledged, as are the comments from Gina Porter on an earlier version of this paper. We also thank Ishmael Adams from the Kgautswane Community Centre for ably assisting with fieldwork.

\section{REFERENCES}

Adewunmi, T., \& Francis, K. (2013). 'An Appraisal of Road Condition Effect on Rural Transportation in Sekyere Central District of the Ashanti Region of Ghana'. Journal of Transportation Technologies, 3:4.

Barwell, I. (1996). Transport and the Village: Findings from African Village-Level Travel and Transport Surveys and Related Studies. World Bank Discussion Paper No. 344, The World Bank. Washington, D.C.

Boudreaux, K. (2006). Taxing Alternatives: Poverty Alleviation and the South African Taxi/Minibus Industry. Mercatus Policy Series. Policy Comment No. 3. George Mason University. (http://works.bepress.com/karol_boudreaux/7) 
Broegaard, E., Freeman, T., \& Schwensen, C. (2011). 'Experience from a phased mixedmethods approach to impact evaluation of Danida support to rural transport infrastructure in Nicaragua'. Journal of development effectiveness,3:1, pp. 9-27.

Bushbuckridge Local Municipality, (2010a). Integrated Development Plan (IDP) 2010/11. Bushbuckridge. South Africa (http://cgta.mpg.gov.za/IDP/Ehlanzeni2010-11/Bush201011.pdf)

Bushbuckridge Local Municipality, (2010b). Spatial Development Framework (SDF). Bushbuckridge. South Africa.

(http://www.bushbuckridge.gov.za/Publications/Bushbuckridge\%20SDF_1Nov2010.doc)

Ellis, S.D., and Hine, J.L. (1998). The Provision of Rural Transport Services: Approach Paper. SSATP Working Paper No. 37. The World Bank: Washington, D.C.

Ericson, M. (2011). 'Pickup Modifications for Rural Transport Services in Cambodia'. Journal of Public Transportation, 14:1, pp. 57.

Gannon, C., and Liu, Z. (1997). Poverty and Transport. Transportation Water and Urban Development Discussion Paper 30. World Bank, Transport Division, Washington, D.C. (http://siteresources.worldbank.org/INTURBANTRANSPORT/Resources/twu-30.pdf)

Gilbert, A. (2008). 'Bus Rapid Transit: Is Transmilenio a miracle cure?' Transport Reviews, 28:4, pp. $439-467$.

Gray, D., Farrington, J., Shaw, J., Martin, S., \& Roberts, D. (2001). 'Car dependence in rural Scotland: transport policy, devolution and the impact of the fuel duty escalator'. Journal of Rural Studies, 17:1, pp. 113-125.

Gray, D., Shaw, J., \& Farrington, J. (2006). 'Community transport, social capital and social exclusion in rural areas'. Area, 38:1, pp. 89-98.

Greater Tubatse Local Municipality, (2010). Integrated Development Plan (IDP) 2010/11. Burgersfort. South Africa. (http://www.tubatse.gov.za/docs/idp/GTM\%20IDP\%20201011.pdf)

Gwilliam, K. (2008). 'Bus transport: Is there a regulatory cycle?' Transportation Research Part A: Policy and Practice, 42:9, pp. 1183-1194.

Hettige, H. (2006). When do rural roads benefit the poor and how? An in-depth analysis based on case studies. Asian Development Bank.

(http://www.ecology.ethz.ch/education/TRE_content/Rural_roads_and_poverty.pdf)

Howe, J. (1981). The Impact of Rural Roads on Poverty Alleviation: A Review of the Literature. International Labour Office, Income Distribution and Employment Programme, Working Paper No. 106.

Howe, J. (2003). 'Filling the middle': Uganda's appropriate transport services. Transport Reviews, 23:2, pp.161-176.

Kamruzzaman, M., \& Hine, J. (2011). 'Participation index: a measure to identify rural transport disadvantage?'. Journal of Transport Geography, 19:4, pp. 882-899. 
Khandker, S. R., Bakht, Z., \& Koolwal, G. B. (2009). 'The poverty impact of rural roads: evidence from Bangladesh'. Economic Development and Cultural Change, 57:4, pp. 685722.

Lebo, J., and Schelling, D. (2001). Design and appraisal of rural transport infrastructure: Ensuring basic access for rural communities. World Bank Technical Paper no. 496. The World Bank, Washington, D.C.

Makhuduthamaga Local Municipality, (2010). Integrated Development Plan (IDP) 2010/11. Jane Furse. South Africa. (http://www.makhuduthamaga.gov.za/docs/idp/20122013\%20MLM\%20IDP.pdf)

Mu, R., \& Van de Walle, D. (2011). 'Rural roads and local market development in Vietnam'. The Journal of Development Studies, 47:5, pp. 709-734.

Parkhurst, G., Galvin, K., Musselwhite, C., Phillips, J., Shergold, I., \& Todres, L. (2014). 'Beyond transport: understanding the role of mobilities in connecting rural elders in civic society'. Countryside Connections: Older People, Community and Place in Rural Britain, Hagan Hennesy et al. (eds), Policy Press: Bristol.

Porter, G. (2011). 'I think a woman who travels a lot is befriending other men and that's why she travels': mobility constraints and their implications for rural women and girls in subSaharan Africa. Gender, place and culture, 18:01, pp. 65-81.

Porter, G., Hampshire, K., Abane, A., Munthali, A., Robson, E., Mashiri, M., Tanle, A., Maponya, G., \& Dube, S. (2012). 'Child porterage and Africa's transport gap: evidence from Ghana, Malawi and South Africa'. World Development, 40:10, pp. 2136-2154.

Porter, G., Tewodros, A., Bifandimu, F., Gorman, M., Heslop, A., Sibale, E., Awadh, A. \& Kiswaga, L. (2013). 'Transport and mobility constraints in an aging population: health and livelihood implications in rural Tanzania'. Journal of Transport Geography, Vol. 30, pp. 161-169.

Raballand, G., Thornton, R., Yang, D., Goldberg, J., Keleher, N., \& Müller, A. (2011). Are rural road investments alone sufficient to generate transport flows? Lessons from a randomized experiment in rural Malawi and policy implications (Policy Research Working Paper 5535). Washington, DC: World Bank. (http://elibrary.worldbank.org/doi/pdf/10.1596/1813-94505535).

Schalekamp, H., \& Behrens, R. (2010). 'Engaging paratransit on public transport reform initiatives in South Africa: A critique of policy and an investigation of appropriate engagement approaches'. Research in Transportation Economics,29:1, pp.371-378.

Shergold, I., and Parkhurst, G. (2012). 'Transport-related social exclusion amongst older people in rural Southwest England and Wales'. Journal of Rural Studies, 28(4), pp.412-421.

Smith, N., Hirsch, D., and Davis, A. (2012). 'Accessibility and capability: the minimum transport needs and costs of rural households'. Journal of Transport Geography, Vol. 21, pp. 93101, March 2012. 
Starkey, P., Ellis, S., Hine, J., and Ternell, A. (2002). Improving Rural Mobility: Options for Developinng Motorized and Nonmotorized Transport in Rural Areas. World Bank Technical Paper. The World Bank, Washington, D.C.

Van de Walle, D. (2002). 'Choosing rural road investments to help reduce poverty'. World Development, 30:4, pp. 575-589.

Velaga, N. R., Beecroft, M., Nelson, J. D., Corsar, D., and Edwards, P. (2012). 'Transport poverty meets the digital divide: accessibility and connectivity in rural communities'. Journal of Transport Geography, Vol. 21, pp. 102-112.

Venter, C., and Venkatesh, A. (2009). Modeling captivity and the demand for motorised transport in rural areas of South Africa. Paper presented at 12th International Conference on Travel Behaviour Research, Jaipur, India. December 2009. (http://repository.up.ac.za/handle/2263/13043).

Venter, C. (2013). 'The lurch towards formalisation: Lessons from the implementation of BRT in Johannesburg, South Africa'. Research in Transportation Economics 39 (2013), pp. 114120.

Washington, S.P., Karlaftis, M.G., and Mannering, F.L. (2003). Statistical and Econometric Methods for Transportation Data Analysis. Chapman and Hall/CRC. 


\begin{tabular}{|c|c|c|c|c|c|c|c|c|c|}
\hline \multicolumn{10}{|c|}{ Table 1: Summary of route lengths by road condition } \\
\hline \multirow{3}{*}{ Local Authority } & \multirow{3}{*}{$\begin{array}{l}\text { No. of } \\
\text { Routes }\end{array}$} & \multirow{2}{*}{\multicolumn{2}{|c|}{$\begin{array}{c}\text { Route length }(\mathrm{km}) \text { per } \\
\text { road type }\end{array}$}} & \multirow{3}{*}{$\begin{array}{c}\text { Total } \\
\text { route } \\
\text { length } \\
(\mathrm{km})\end{array}$} & \multirow{3}{*}{$\begin{array}{c}\text { Route- } \\
\text { km per } \\
1,000 \\
\text { people }\end{array}$} & \multicolumn{4}{|c|}{$\%$ of route-km per road condition } \\
\hline & & & & & & \multirow[b]{2}{*}{ Excellent } & \multirow[b]{2}{*}{ Good } & \multirow[b]{2}{*}{ Fair } & \multirow{2}{*}{$\begin{array}{c}\text { Poor/ } \\
\text { Very } \\
\text { poor }\end{array}$} \\
\hline & & Surfaced & Gravel & & & & & & \\
\hline Greater Tubatse & 23 & 574.9 & 160.2 & 735.1 & 2.140 & $4.7 \%$ & $52.0 \%$ & $15.3 \%$ & $28.0 \%$ \\
\hline ALL & 75 & 1050.8 & 590.1 & 1640.9 & 1.422 & $11.5 \%$ & $45.9 \%$ & $19.4 \%$ & $23.3 \%$ \\
\hline
\end{tabular}

Sources: Primary data collection and authors' calculations. Population estimates obtained from Bushbuckridge LM (2010b), Makhuduthamaga LM (2010), and Greater Tubatse LM (2010). Road condition based on visual assessment 


\begin{tabular}{|c|c|c|c|c|}
\hline \multicolumn{5}{|c|}{ Table 2: Public transport supply per mode in case study areas } \\
\hline \multirow{2}{*}{$\begin{array}{l}\text { Vehicle type } \\
\text { (Service type) }\end{array}$} & \multirow[b]{2}{*}{ Road type } & \multicolumn{3}{|c|}{ Total daily vehicle frequency (vehicle trips per 9-hour day) } \\
\hline & & Makhuduthamaga & Bushbuckridge & Greater Tubatse \\
\hline \multirow{3}{*}{ Bakkie (Informal) } & Gravel & 138 (16.9\%) & $103(10.9 \%)$ & $130(20.8 \%)$ \\
\hline & Surfaced & 35 (3.5\%) & $28(3.0 \%)$ & $55(8.8 \%)$ \\
\hline & ALL & 203 (20.4\%) & 131 (13.9\%) & 185 (29.6\%) \\
\hline \multirow{3}{*}{ Minibus (Informal) } & Gravel & $98(9.8 \%)$ & $163(17.3 \%)$ & $97(15.5 \%)$ \\
\hline & Surfaced & 645 (64.9\%) & $594(63.1 \%)$ & $295(47.1 \%)$ \\
\hline & ALL & 743 (74.8\%) & 757 (80.5\%) & 392 (62.6\%) \\
\hline \multirow{3}{*}{$\begin{array}{l}\text { Other small vehicle }{ }^{1} \\
\text { (Informal) }\end{array}$} & Gravel & $17(1.7 \%)$ & $17(1.8 \%)$ & $15(2.4 \%)$ \\
\hline & Surfaced & $2(0.2 \%)$ & $5(0.5 \%)$ & $0(0 \%)$ \\
\hline & ALL & $19(1.9 \%)$ & $22(2.3 \%)$ & $15(2.4 \%)$ \\
\hline \multirow{3}{*}{ Bus (formal) } & Gravel & $10(1.0 \%)$ & $10(1.1 \%)$ & $12(1.9 \%)$ \\
\hline & Surfaced & $18(1.8 \%)$ & $21(2.2 \%)$ & $22(3.5 \%)$ \\
\hline & ALL & $28(2.8 \%)$ & 31 (3.3\%) & $34(5.4 \%)$ \\
\hline ALL TYPES & ALL & $993(100 \%)$ & $941(100 \%)$ & $626(100 \%)$ \\
\hline
\end{tabular}

(1) Other informal include Kartjiebans (old minibuses and vans) and private cars operating for-hire public transport services, i.e. smaller vehicles with capacities of between 6 and 12 passengers.

Sources: Primary data collection and authors' calculations 


\section{Table 3: Public transport demand and capacity per mode in case study areas}

\begin{tabular}{|c|c|c|c|c|}
\hline \multirow{2}{*}{$\begin{array}{l}\text { Vehicle } \\
\text { type } \\
\text { (Service } \\
\text { type) }\end{array}$} & & \multicolumn{3}{|c|}{ Case study area } \\
\hline & & Makhuduthamaga & Bushbuckridge & Greater Tubatse \\
\hline \multirow{3}{*}{$\begin{array}{l}\text { Bakkie } \\
\text { (Informal) }\end{array}$} & $\begin{array}{l}\text { Demand (passenger } \\
\text { trips per 9-hour day) }\end{array}$ & 838 & 731 & 938 \\
\hline & $\begin{array}{c}\text { Capacity (seats per 9- } \\
\text { hour day) }\end{array}$ & $1624(11.1 \%)$ & $1048(7.7 \%)$ & $1480(15.7 \%)$ \\
\hline & Utilisation (\%) & $52 \%$ & $70 \%$ & $63 \%$ \\
\hline \multirow{3}{*}{$\begin{array}{l}\text { Minibus } \\
\text { (Informal) }\end{array}$} & $\begin{array}{l}\text { Demand (passenger } \\
\text { trips per 9-hour day) }\end{array}$ & 7104 & 7343 & 3712 \\
\hline & $\begin{array}{c}\text { Capacity (seats per 9- } \\
\text { hour day) }\end{array}$ & $10859(74.1 \%)$ & 10485 (77.1\%) & $5713(60.5 \%)$ \\
\hline & Utilisation (\%) & $65 \%$ & $70 \%$ & $65 \%$ \\
\hline \multirow{3}{*}{$\begin{array}{l}\text { Other } \\
\text { small } \\
\text { vehicle } \\
\text { (Informal) }\end{array}$} & $\begin{array}{l}\text { Demand (passenger } \\
\text { trips per 9-hour day) }\end{array}$ & 155 & 122 & 54 \\
\hline & $\begin{array}{c}\text { Capacity (seats per 9- } \\
\text { hour day) }\end{array}$ & 237 (1.6\%) & 211 (1.6\%) & $60(0.6 \%)$ \\
\hline & Utilisation (\%) & $65 \%$ & $58 \%$ & $90 \%$ \\
\hline \multirow{3}{*}{$\begin{array}{l}\text { Bus } \\
\text { (formal) }\end{array}$} & $\begin{array}{l}\text { Demand (passenger } \\
\text { trips per 9-hour day) }\end{array}$ & 995 & 1667 & 1052 \\
\hline & $\begin{array}{c}\text { Capacity (seats per 9- } \\
\text { hour day) }\end{array}$ & $1927(13.2 \%)$ & 1857 (13.6\%) & $2190(23.2 \%)$ \\
\hline & Utilisation (\%) & $52 \%$ & $90 \%$ & $48 \%$ \\
\hline \multirow{3}{*}{$\begin{array}{l}\text { ALL } \\
\text { MODES }\end{array}$} & $\begin{array}{l}\text { Demand (passenger } \\
\text { trips per 9-hour day) }\end{array}$ & 9092 & 9863 & 5756 \\
\hline & $\begin{array}{c}\text { Capacity (seats per 9- } \\
\text { hour day) }\end{array}$ & 14647 (100\%) & 13601 (100\%) & $9443(100 \%)$ \\
\hline & Utilisation (\%) & $62 \%$ & $73 \%$ & $61 \%$ \\
\hline
\end{tabular}

(1) Other informal include Kartjiebans (old minibuses and vans) and private cars operating for-hire public transport services, i.e. smaller vehicles with capacities of between 6 and 12 passengers.

Source: Primary data collection and authors' calculations 


\begin{tabular}{|c|c|c|c|c|c|c|}
\hline \multirow{2}{*}{$\begin{array}{l}\text { Type of } \\
\text { factor }\end{array}$} & \multirow[t]{2}{*}{ Variable } & \multirow{2}{*}{$\begin{array}{l}\text { Mean } \\
\text { value }^{2}\end{array}$} & \multicolumn{2}{|c|}{$\begin{array}{l}\text { Model 1: All informal } \\
\text { modes }\end{array}$} & \multicolumn{2}{|c|}{ Model 2: Minibus mode } \\
\hline & & & Estimate & $P$ value & Estimate & $P$ value \\
\hline Infrastructure & $\begin{array}{l}\text { \%GRAVPOOR: Percentage of } \\
\text { route that is gravel and } \\
\text { in poor condition }\end{array}$ & 21.5 & -0.004 & 0.089 & $-0.011 * *$ & 0.010 \\
\hline Infrastructure & $\begin{array}{l}\text { FORMALRANK: } 1 \text { if formal } \\
\text { rank is used at start or } \\
\text { end of route }\end{array}$ & 0.73 & -0.083 & 0.696 & 0.799* & 0.037 \\
\hline Demand & $\begin{array}{l}\text { POPDENS: Average } \\
\text { population density } \\
\text { (persons/ha) within } \\
0.5 \mathrm{~km} \text { of route }\end{array}$ & 12.7 & $0.020 *$ & 0.011 & $0.030 * *$ & 0.002 \\
\hline Demand & $\begin{array}{l}\text { ECONACT: Average GVA }{ }^{1} \\
\text { (Rands/ha) within } 2 \mathrm{~km} \\
\text { of route }\end{array}$ & 58.7 & $0.004 * *$ & 0.000 & $0.006 * *$ & 0.000 \\
\hline Route & $\begin{array}{l}\text { ROUTELENGTH: } 1 \text { if route is } \\
\text { longer than } 30 \mathrm{~km} \text { (one- } \\
\text { way) }\end{array}$ & 0.17 & $-0.572 *$ & 0.038 & -0.384 & 0.152 \\
\hline Constant & CONSTANT & - & $2.049 * *$ & 0.000 & 0.694 & 0.062 \\
\hline \multicolumn{3}{|c|}{$\begin{array}{c}\text { Mean value of dependent variable (Trip frequency per } \\
\text { route) }\end{array}$} & \multicolumn{2}{|c|}{11.29} & \multicolumn{2}{|c|}{8.15} \\
\hline \multicolumn{3}{|l|}{$\mathrm{N}=$} & \multicolumn{2}{|c|}{151} & \multicolumn{2}{|c|}{151} \\
\hline
\end{tabular}

Notes: (1) GVA = Gross Value Added, a measure of all economic output generated within buffer zone around route.

(2) Mean value of independent variable

*Significant at $95 \%$

** Significant at $99 \%$ 


\begin{tabular}{|l|l|c|c|c|c|c|}
\hline \multicolumn{2}{|c|}{ Table 5: Regression results: Factors explaining average fare per kilometer of informal } \\
transport services
\end{tabular}

Notes: (1) Marginal effects calculated as increase in fare associated with one unit increase in independent variable (or increase to $100 \%$ for \%GRAVPOOR and \%NONTAXI). Based on average fare in the sample (R13.58). Only calculated for significant variables.

(2) Mean value of independent variable

(3) PT=Public transport

*Significant at 95\%

**Significant at 99\% 


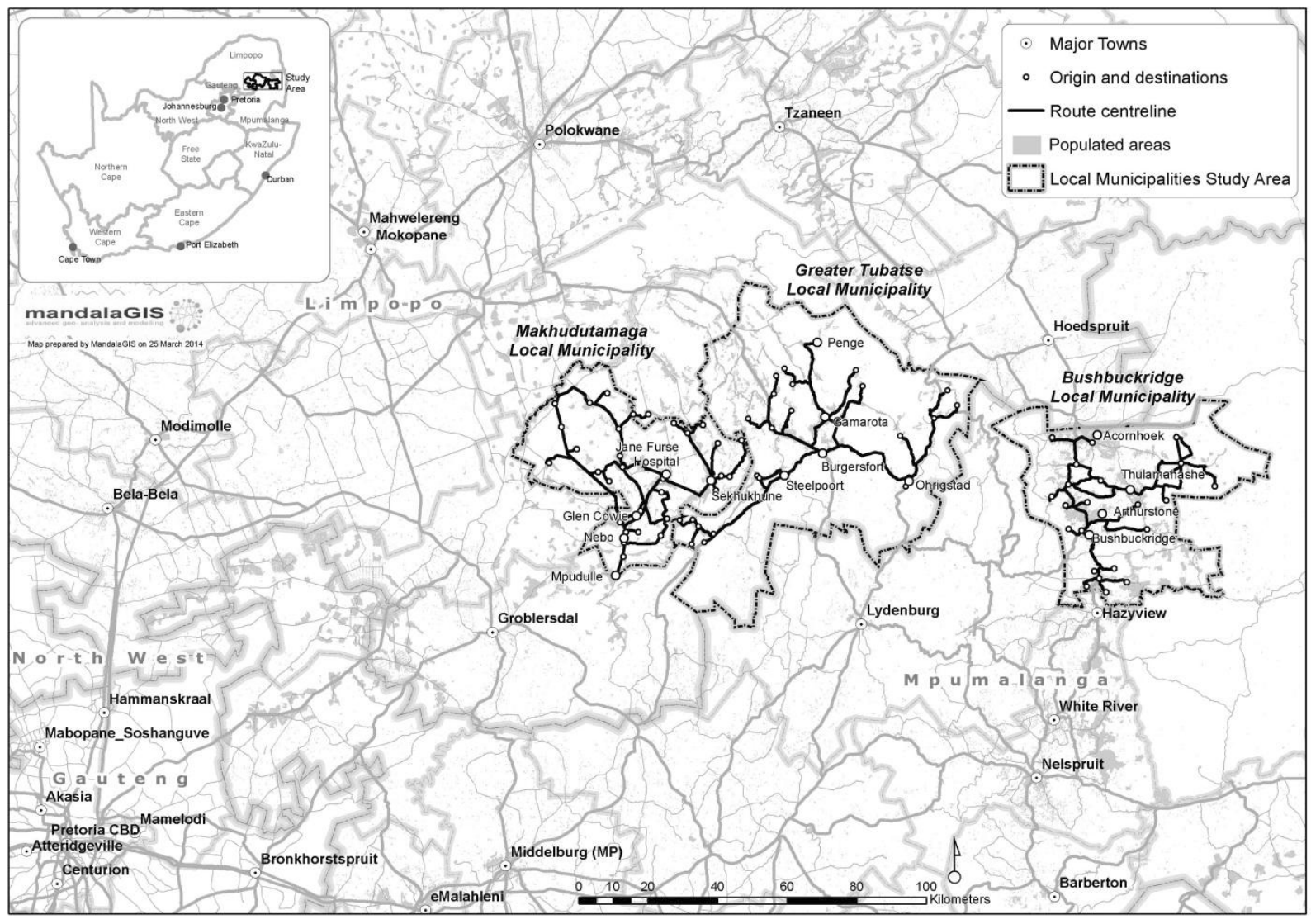

Figure 1: Location of case study areas, and public transport routes surveyed in each area 


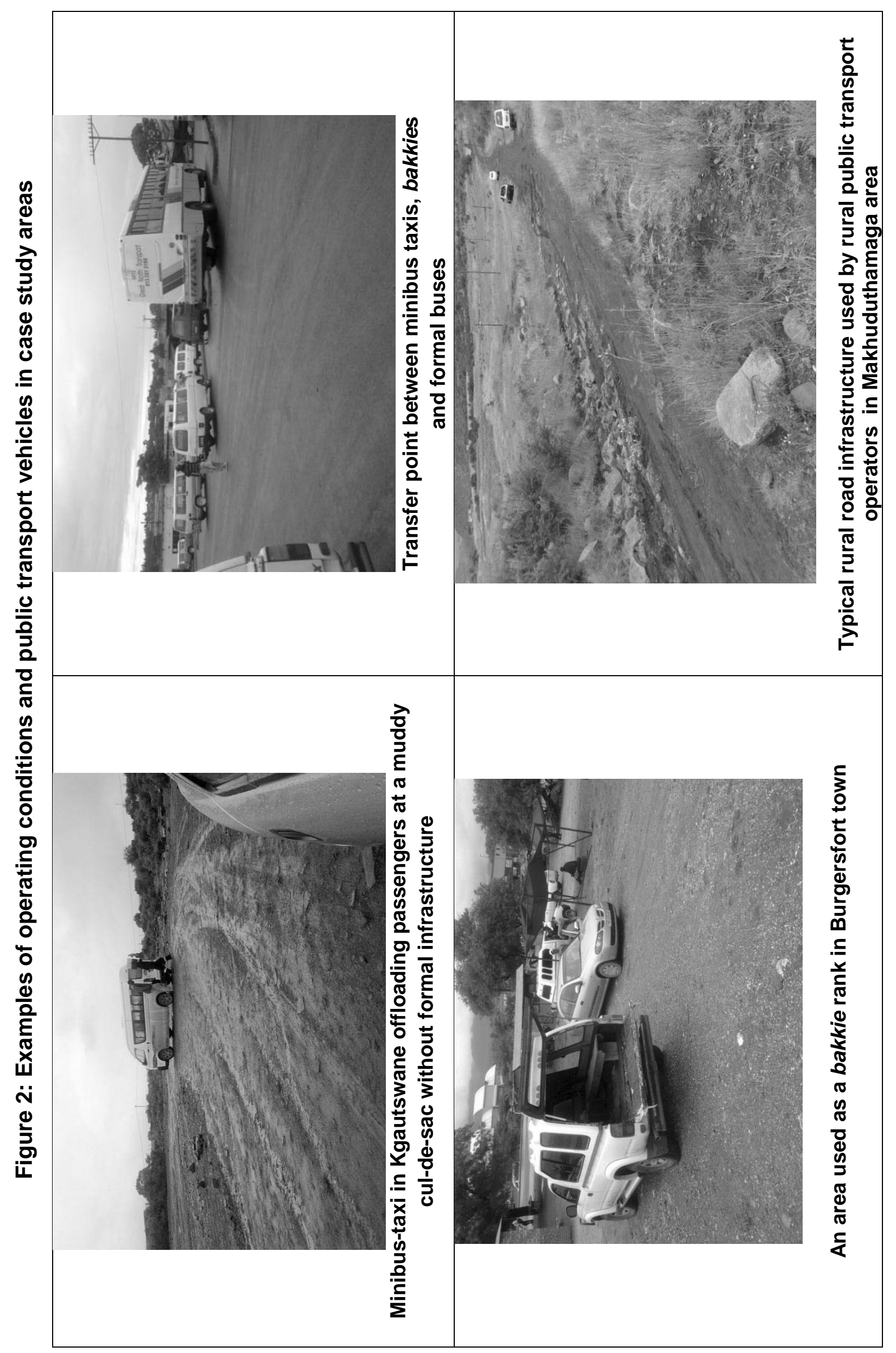

$N$
$\stackrel{0}{\frac{1}{5}}$
은 


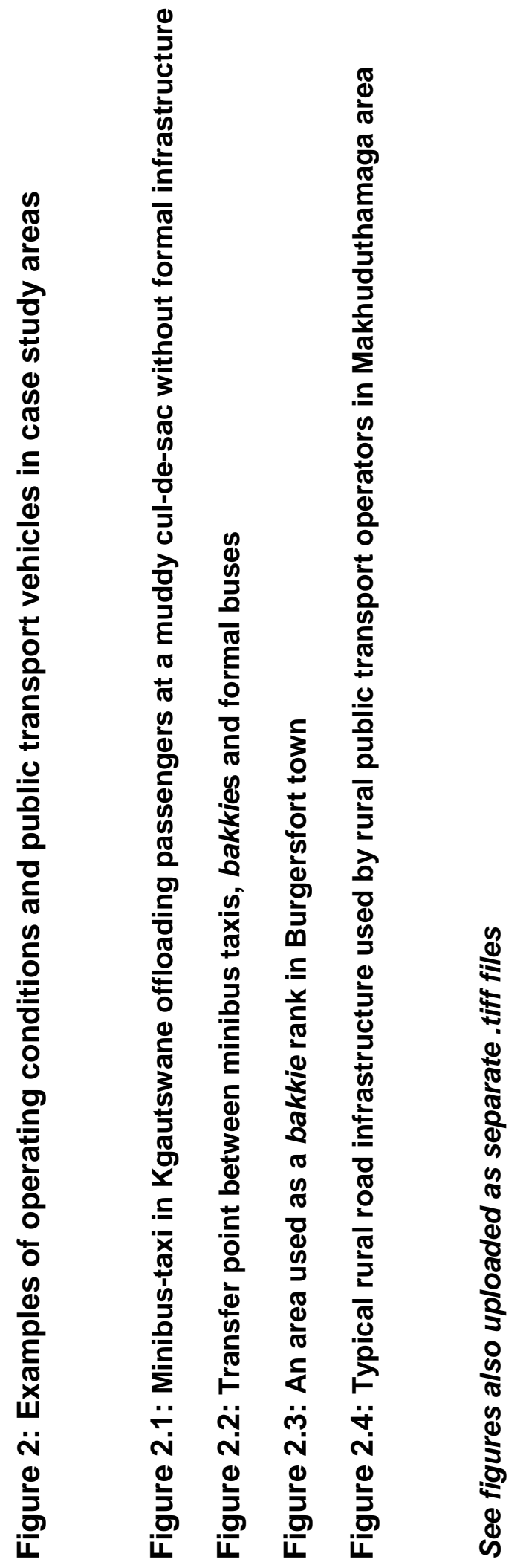




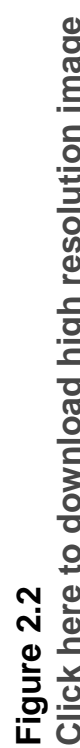

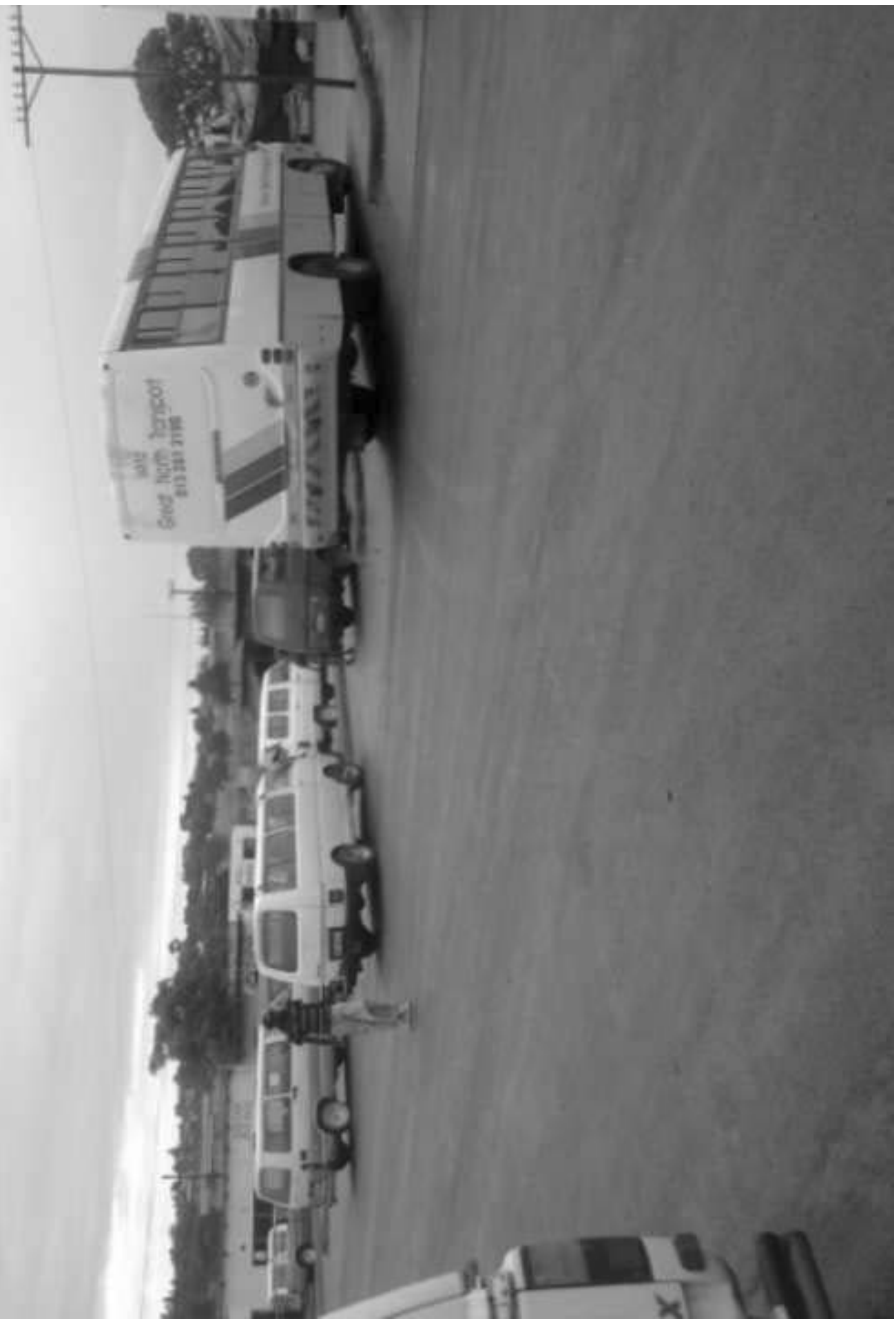




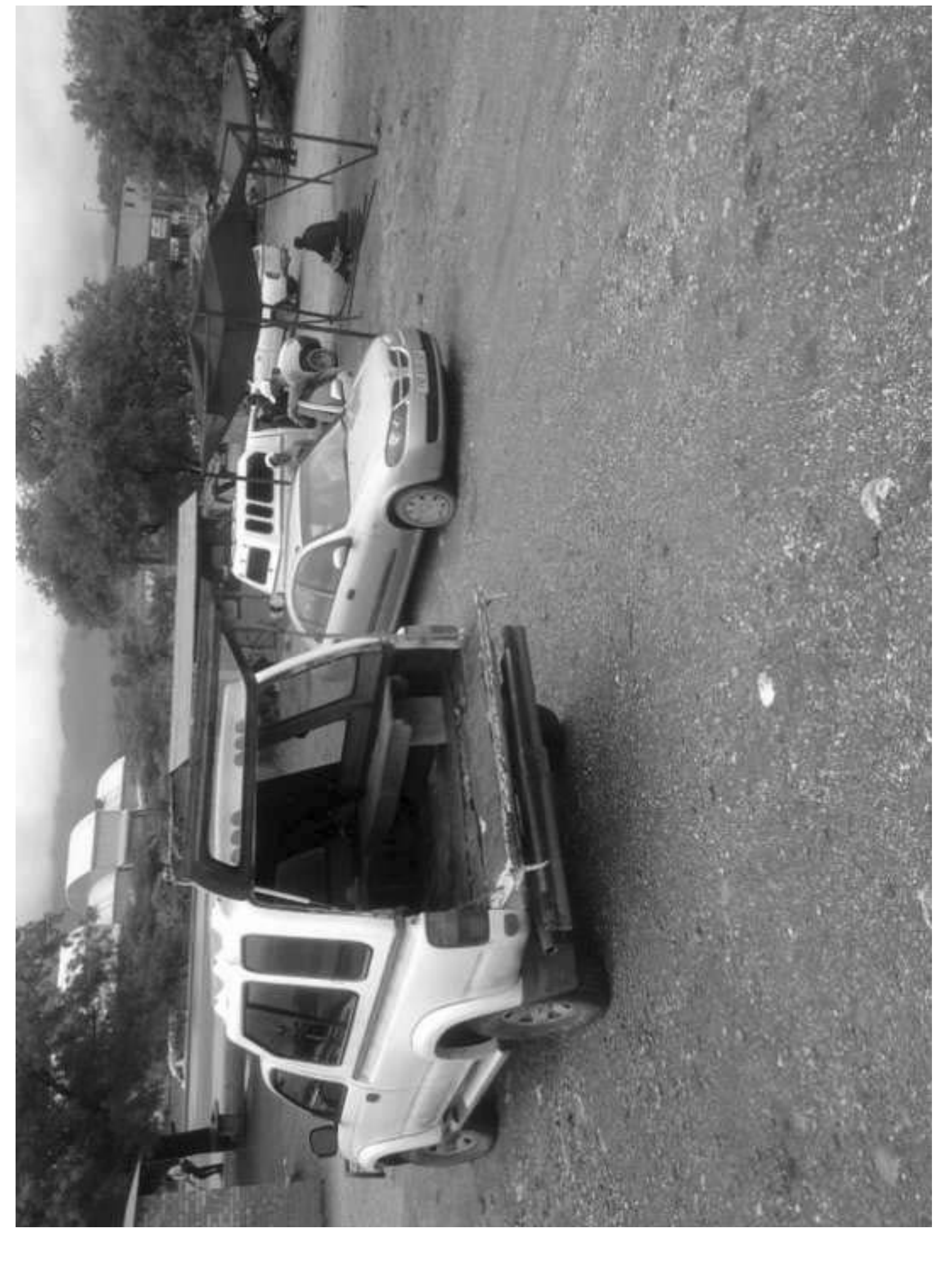




\section{ai}

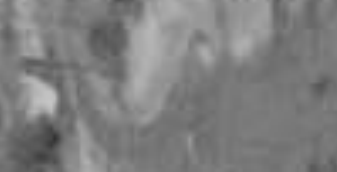

(i)

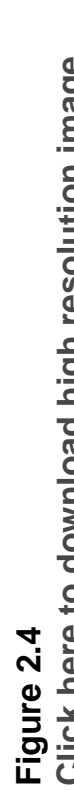

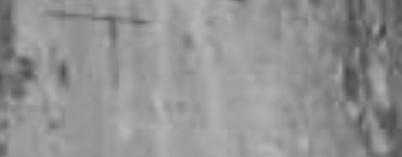

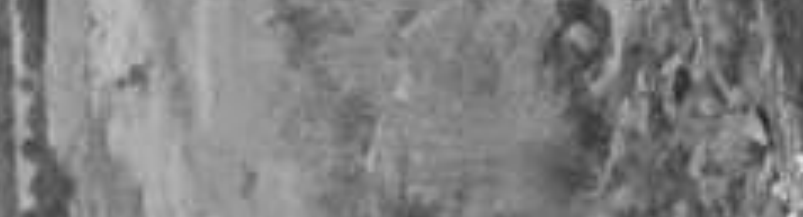

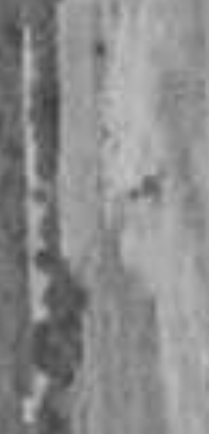

(48)

P.W.

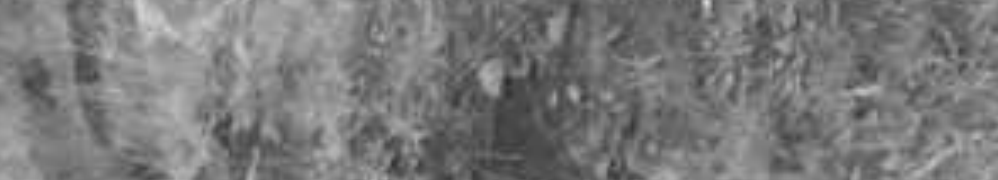

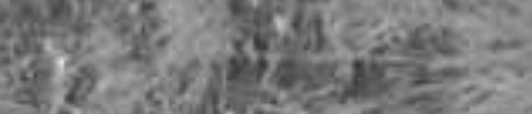
$\cos 20$

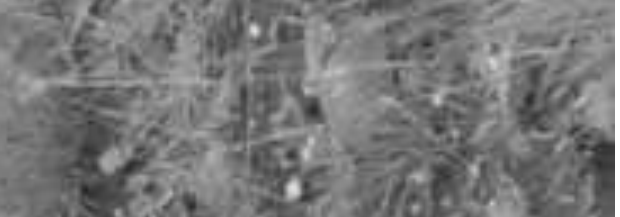

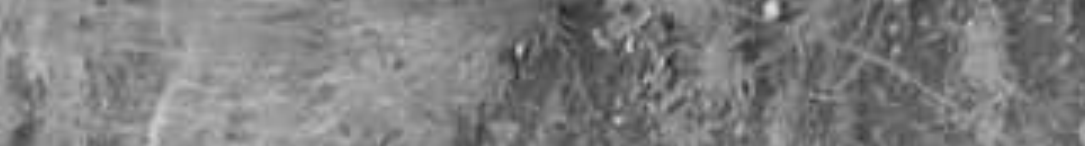

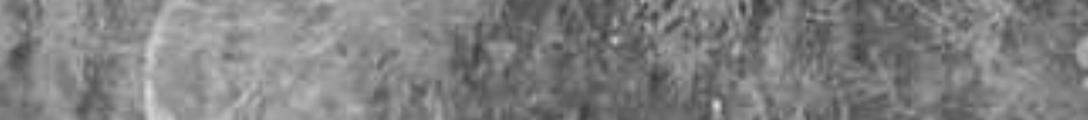

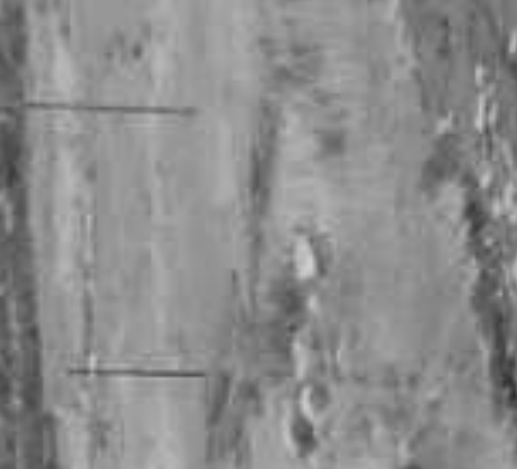



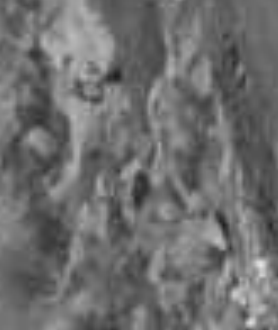

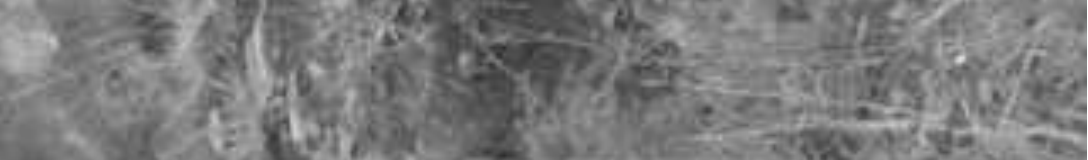

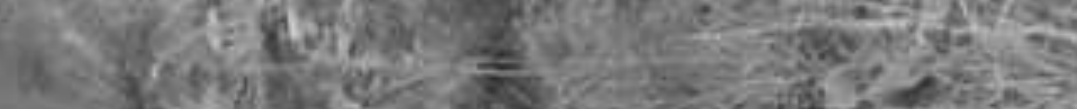

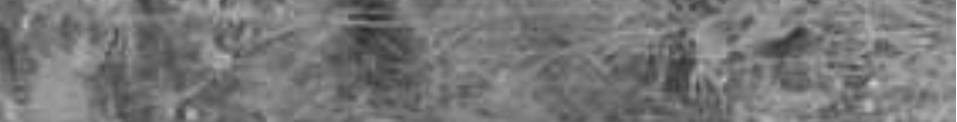

a

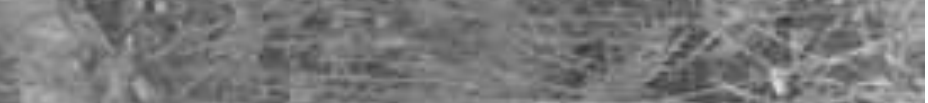
atingen

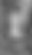
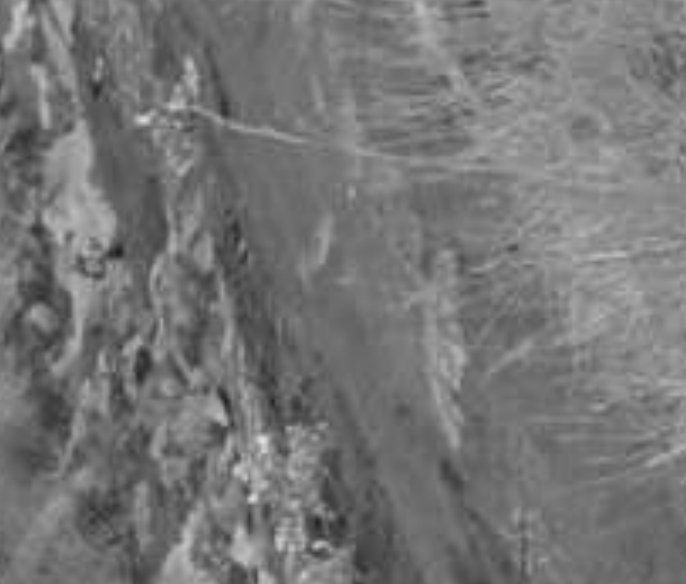


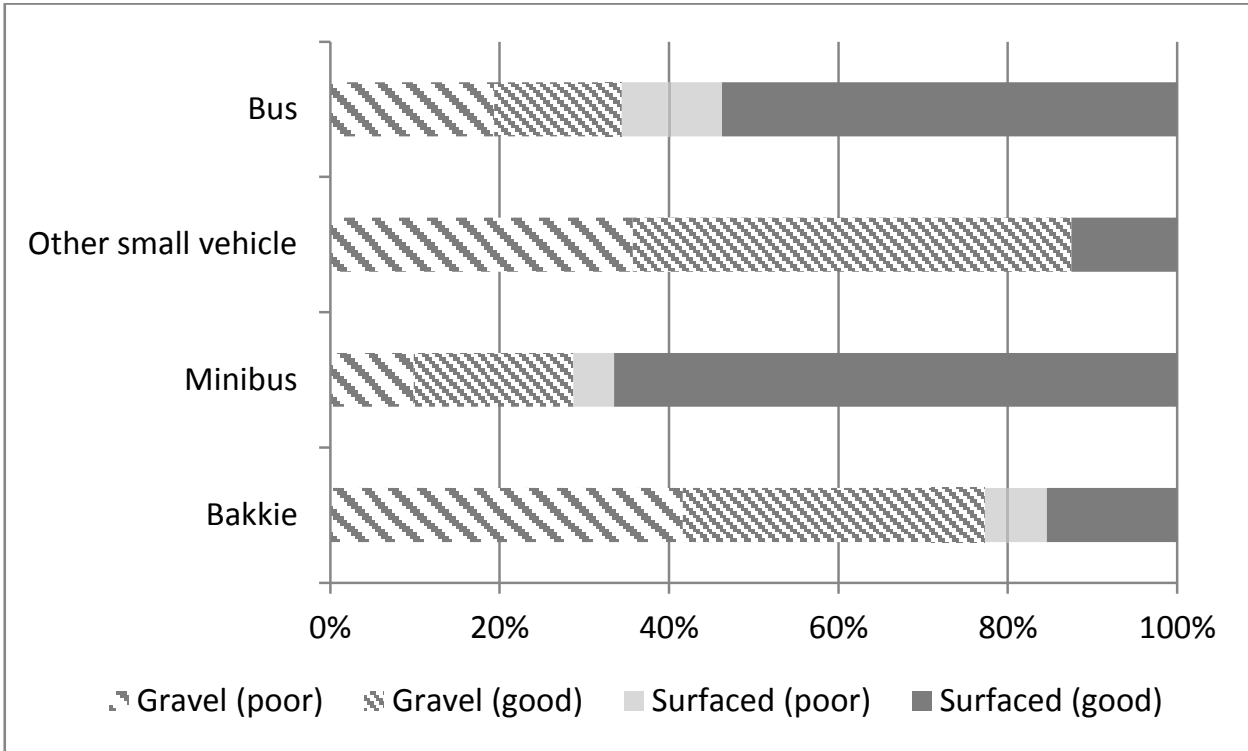

Figure 3: Percentage of trips operated by different modes per road type and condition (all areas combined)

Sources: Primary data collection and authors' calculations 


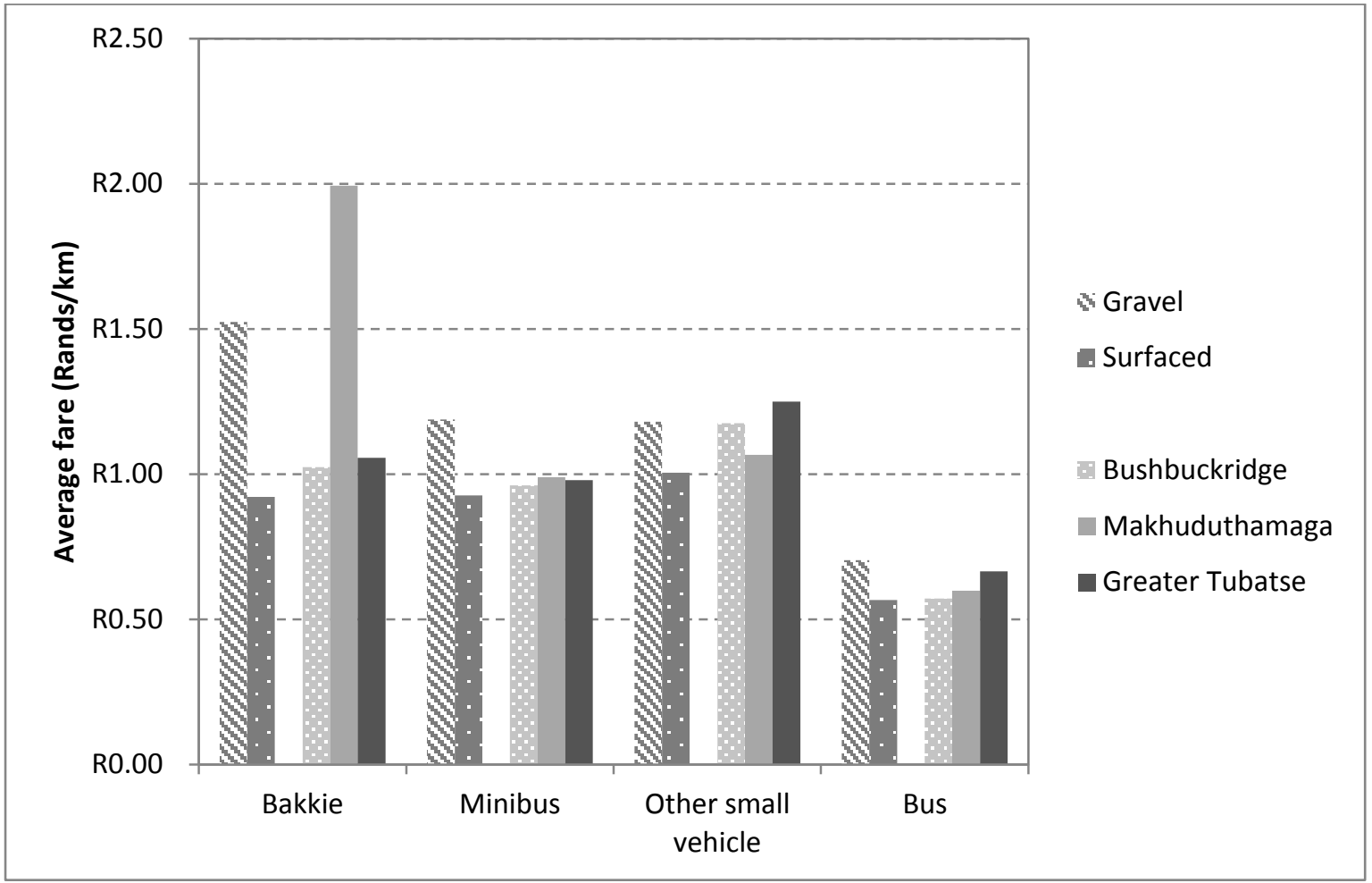

Figure 4: Average fare per kilometer per mode, road type and area

Sources: Primary data collection and authors' calculations 